\title{
Physico-chemical parameters of water and sediment during spring period in parts off bay of Bengal, Bangladesh
}

\begin{abstract}
The present investigation encompassed to give a quick overview of some physicochemical parameters of water and sediment in the northern part of Bay of Bengal during spring period in March and April. The physico-chemical parameters water temperature $\left(23-32^{\circ} \mathrm{C}\right)$, salinity $(22-34 \%), \mathrm{pH}(6.0-7.8)$ and $\mathrm{DO}(1.94-6.32 \mathrm{ml} / 1)$ and sediment temperature $\left(17-23^{\circ} \mathrm{C}\right)$, salinity $(3.9-6.7 \%), \mathrm{pH}(6-7.5)$, organic carbon $(0.98-3.63 \%)$ and organic matter $(1.68-6.24 \%)$ were recorded. Sediment salinity was inversely correlated with water salinity $(\mathrm{r}=-0.576, \mathrm{P}<0.05, \mathrm{df}=10)$ and sediment $\mathrm{pH}$ showed a positive relation with water $\mathrm{pH}(\mathrm{r}=0.68, \mathrm{P}<0.05, \mathrm{df}=10)$. No published report was found on physico-chemical parameter of subsurface water and surficial sediment in the Bay of Bengal off Bangladesh coast. Therefore, the present results focus a baseline data for developing water and sediment quality index of the coastal zone in Bangladesh territory.
\end{abstract}

Keywords: physico-chemical parameters, water, sediment, Bangladesh coast, baseline
Volume 3 Issue 3 - 2018

\author{
Rashedul Alam Chowdhury SM, Mohammad \\ Zafar \\ Institute of Marine Sciences and Fisheries, University of \\ Chittagong, Bangladesh
}

Correspondence: Rashedul Alam Chowdhury M, Institute
of Marine Sciences and Fisheries, University of Chittagong,
Chittagong- 433I, Bangladesh, Tel 8803 I7I0 347, 880। 8I8I 0483 5, Fax 8803 1726 310, Email rac.imsf@gmail.com

Received: April 28, 2017| Published: May 21, 2018

\section{Introduction}

The coastal oceans have become very important places for outdoor research around the world from geological, hydrological and biological point of view. Hydrological features, bio-productivity of coastal transition zones is so dynamic that variations take place monthly, daily and even hourly. Physico-chemical factors of coastal waters, mainly the salinity, temperature, dissolved oxygen content are variable condition due to the tides and also freshwater discharge by network of rivers. ${ }^{1}$ The ecology of the Bay of Bengal has been studied in relation to coastal edaphic features by Islam. ${ }^{2}$ The physicochemical conditions of water of the coastal zone are not well known but the environmental condition of the Bay of Bengal may be considered as representing those of coastal areas. ${ }^{2}$ In order to understand the fertility of any aquatic system for its possible use, a study on its physicochemical characteristics of water and sediment is indispensable. Many workers conducted investigations to record physical, chemical and biological parameters of the Bay of Bengal near Bangladesh but information available in Bangladesh showed about only water qualities Mahmood et al. $^{3}$ Bangladesh situated one of the world's largest delta and is interlaced with an intricate system of rivers and many tidal channels, which carry downstream a large quantity of sediment. The annual load carried in suspension is approximately 1.7 billion tons. ${ }^{4}$ This sediment plays an important role in the nutrient regeneration and primary productivity of Bangladesh coast. Sediment $\mathrm{pH}$ is the most important factor of nutrient availability $^{5}$ and the organic carbon is directly related with mud percentage in sediment. ${ }^{6}$ The amount of organic carbon in sediments is influenced by both physical and biological factors and may in turn influence the quality and availability of food sources benthic faunal communities. Zafar et al. ${ }^{7}$ reported organic carbon as the index of sediment fertility. Estuaries and others coastal ecosystems forms a significant component of global carbon balance as intense processing of organic matter, originating from fluvial inputs, local production or lateral inputs from marshes and mangrove take place. ${ }^{8}$ Organic matter binds mineral particles in to granules that are largely responsible for the loose, easily manage condition of productive sediment and is the main source of energy for sediment organism. Texture is the relative proportions of the different size groups of separates. The rate and extent of many important physical and chemical reactions in sediment are governed by texture. ${ }^{9}$ The objectives of the present research work were to determine physico-chemical parameters of subsurface water and surficial sediment of the most productive and vulnerable coastal ocean of Bangladesh.

\section{Materials and methods}

Water samples were collected randomly from six stations located in between $21^{\circ} 39^{\prime} 00^{\prime \prime} \mathrm{N}$ to $22^{\circ} 10^{\prime} 00^{\prime \prime} \mathrm{N}$ latitude and $91^{\circ} 22^{\prime} 10^{\prime \prime} \mathrm{E}$ to $91^{\circ} 50^{\prime} 10^{\prime \prime} \mathrm{E}$ longitude during March 2007 and from five stations located in between $21^{\circ} 02^{\prime} 00^{\prime \prime} \mathrm{N}$ to $21^{\circ} 38^{\prime} 00^{\prime \prime} \mathrm{N}$ latitude and $89^{\circ} 36^{\prime} 00^{\prime \prime} \mathrm{E}$ to $91^{\circ} 37^{\prime} 00^{\prime} \mathrm{E}$ longitude in April 2007 from northern part of the Bay of Bengal ${ }^{10}$ (Figure 1). Samples were collected by Nansen bottle from subsurface level ( $\geq 4 \mathrm{~m}$, ranged between 05 to $16 \mathrm{~m}$ ) and sampling depths were detected by sounding technique (Eco- sounder: ModelEURO 3000). Concurrently water temperature, Salinity, $\mathrm{pH}$ were recorded by using a thermometer, refractometer (model: $0 \sim 100 \%$, ATAGO, Japan) and a digital pen pH meter (Model: S237734, Hana Instruments) respectively. Dissolved oxygen content in water samples were analyzed as following the Winkler's method. ${ }^{11}$ piece of foil paper in a thin layer and kept on a shelf in the sediment preparation room until it was air-dry. Sediment salinity was determined following the methods of Petersen. ${ }^{12}$ Sediment texture was detected following the procedure described by Bouyoucos. ${ }^{13}$ Sediment Organic carbon was determined according to the method of Jackson. ${ }^{14}$ Sediment 
Organic Matter was determined according to the method followed by Belaluzzaman. ${ }^{15}$ Correlation and regression analysis were done to assess the relationship among various physico-chemical parameters of water and sediment.

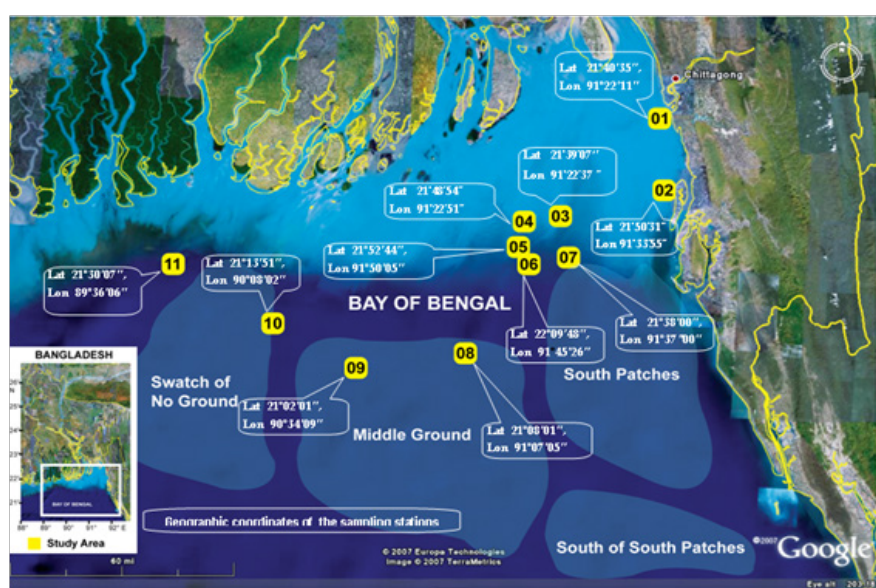

Figure I Map showing the geographical location of the sampling spots in the Bay of Bengal.

Source www.googleearth.com 2007 (modified).

\section{Results}

Physico-chemical parameters of subsurface water viz. salinity, temperature and dissolved oxygen content, $\mathrm{pH}$ were recorded and concurrently sediment temperature, salinity, $\mathrm{pH}$, organic carbon and organic matter were also determined.

The recorded water and sediment parameters stated as:

\section{Physico-chemical parameters of subsurface water}

\section{Temperature}

In the present investigation the average subsurface water temperature was recorded as $28.02+2.49^{\circ} \mathrm{C}$ (Table 1) and varied between $23-32^{\circ} \mathrm{C}$. The maximum $\left(32^{\circ} \mathrm{C}\right)$ value was recorded in the southeastern coast (station 07, down part of Sandip Island) in April and minimum $\left(23^{\circ} \mathrm{C}\right)$ was also observed in April at station 11 near the downstream area of Khulna Sundarban.

\section{Salinity}

The mean water salinity was observed as $28.18+3.72 \%$ (Table 1 ) and ranged between $22-34 \%$. The highest value (34\%) was noticed in a location in the Middle Fishing Ground area at station 08 during April and lowest (22\%) was observed at station 04 in March near the lower parts of the Hatiya Island.

Table I Physico-chemical parameters of water and sediment in the offshore area of Bangladesh coast

\begin{tabular}{|c|c|c|c|c|c|c|c|c|c|c|c|c|c|c|}
\hline \multirow[b]{2}{*}{ Period } & \multirow[b]{2}{*}{$\begin{array}{l}\text { St. } \\
\text { no }\end{array}$} & \multirow[b]{2}{*}{ Lat (N) } & \multirow[b]{2}{*}{ Lon (E) } & \multicolumn{2}{|c|}{$\begin{array}{l}\text { Sampling } \\
\text { depth (m) }\end{array}$} & \multicolumn{2}{|c|}{ Salinity (\%) } & \multicolumn{2}{|l|}{$\mathrm{pH}$} & \multicolumn{2}{|c|}{$\begin{array}{l}\text { Temperature } \\
\left({ }^{\circ} \mathrm{C}\right)\end{array}$} & \multirow{2}{*}{$\begin{array}{l}\text { Water } \\
\text { D.O } \\
(\mathrm{ml} / \mathrm{l})\end{array}$} & \multicolumn{2}{|c|}{ Sediment } \\
\hline & & & & $\mathbf{W}$ & $\mathbf{S}$ & $\mathbf{W}$ & $\mathbf{S}$ & $\mathbf{w}$ & $\mathbf{S}$ & $\mathbf{W}$ & $\mathbf{S}$ & & $\begin{array}{l}\text { Org. C } \\
(\%)\end{array}$ & $\begin{array}{l}\text { Org. } \\
\text { Matter } \\
\text { (\%) }\end{array}$ \\
\hline \multirow{7}{*}{$\begin{array}{l}\text { March } \\
2007\end{array}$} & I & $21^{\circ} 40^{\prime} 35^{\prime \prime}$ & $91^{\circ} 22^{\prime} \mid$ I" & 6.8 & 6.8 & 26.5 & 6.6 & 6.1 & 6.1 & 28 & 23 & 5.9 & 0.98 & 1.68 \\
\hline & 2 & $21^{\circ} 50^{\prime} 3 I^{\prime \prime}$ & $91^{\circ} 33 ’ 55^{\prime \prime}$ & 10.33 & 10.33 & 29 & 6.7 & 6.7 & 6.4 & 28 & 20 & 5.5 & 1.04 & 1.78 \\
\hline & 3 & $21^{\circ} 39^{\prime} 07^{\prime \prime}$ & $91^{\circ} 22 ’ 37 ”$ & II & II & 24 & 5.1 & 6.3 & 6.2 & 31 & 20 & 6.1 & 1.85 & 3.18 \\
\hline & 4 & $21^{\circ} 48,54 "$ & $91^{\circ} 22 ’ 51 ”$ & 8.8 & 8.8 & 22 & 5.5 & 6.5 & 6 & 28 & 22 & 5.8 & 1.76 & 3.03 \\
\hline & 5 & $21^{\circ} 52 ’ 44^{\prime \prime}$ & $91^{\circ} 50 ’ 05 "$ & 14 & 14 & 25 & 5.6 & 6.6 & 6.5 & 29 & 20 & 6.32 & 1.92 & 3.3 \\
\hline & 6 & $22^{\circ} 09^{\prime} 48^{\prime \prime}$ & $91^{\circ} 45^{\prime} 26^{\prime \prime}$ & 10.5 & 10.5 & 25 & 5.2 & 6 & 6.6 & 30 & 21 & 5.7 & 1.97 & 3.39 \\
\hline & 7 & $21^{\circ} 38^{\prime} 00^{\prime \prime}$ & $91^{\circ} 37 ” 00 ”$ & 5 & 12.5 & 32 & 4.3 & 6.9 & 6.9 & 32 & 20 & 4.03 & 1.95 & 3.35 \\
\hline \multirow{4}{*}{$\begin{array}{l}\text { April } \\
2007\end{array}$} & 8 & $21^{\circ} 08^{\prime} 01 "$ & $91^{\circ} 07 ’ 05 ”$ & 7.01 & 14.5 & 34 & 3.9 & 6.9 & 7.1 & 28 & 19 & 2.75 & 1.81 & 3.11 \\
\hline & 9 & $21^{\circ} 02{ }^{\prime} 01 "$ & $90^{\circ} 34^{\prime} 09^{\prime \prime}$ & 16.45 & 66.6 & 32 & 4.5 & 7.7 & 7.5 & 27 & 17 & 1.94 & 3.63 & 6.24 \\
\hline & 10 & $21^{\circ} \mid 3^{\prime} 5 I^{\prime \prime}$ & $90^{\circ} 08^{\prime} 02^{\prime \prime}$ & 14.32 & 23 & 31 & 4.2 & 7.8 & 6.7 & 25 & 19 & 2.5 & 1.72 & 2.96 \\
\hline & II & $21^{\circ} 30^{\prime} 07^{\prime \prime}$ & $89^{\circ} 36^{\prime} 06^{\prime \prime}$ & 10.7 & 10.7 & 29.5 & 4.2 & 6.8 & 6.8 & 23 & 21 & 2.41 & 1.47 & 2.53 \\
\hline Mean & $\ldots$ & $\ldots \ldots$ & $\ldots \ldots$ & 10.45 & 17.16 & 28.18 & 5.07 & 6.8 & 6.62 & 28 & 20 & 4.45 & 1.83 & 3.14 \\
\hline$\pm \mathrm{SD}$ & $\ldots$ & $\ldots \ldots$ & $\ldots \ldots$ & 3.32 & 16.14 & 3.72 & 0.92 & 0.6 & 0.43 & 2 & II & 1.66 & 0.66 & 1.13 \\
\hline
\end{tabular}

NB:W,Water; S, Sediment; Org.,Organic

\section{Hydrogen ion concentration $(\mathrm{pH})$}

In the present investigation $\mathrm{pH}$ value fluctuates in minor magnitude, ranged from 6.0 to 7.8 with an average $6.75 \pm 0.55$ (Table 1). The pick value was recorded during April in station 10 which is in the Swatch of No Ground area and lower value was noticed during March in station 06 at lower Meghna estuary.

\section{Dissolved oxygen (DO)}

In the investigated area the mean DO content in subsurface water was recorded $4.45+1.66 \mathrm{ml} / 1$ (Table 1). The DO content in subsurface water fluctuates greatly during April and minimum value was found $1.94 \mathrm{ml} / 1$ at about $16.45 \mathrm{~m}$ water depth in the Middle Fishing Ground area (station 09) during April.

\section{Surficial sediment parameters}

\section{Temperature}

The average temperature was recorded $20.18 \pm 10.7^{\circ} \mathrm{C}$ (Table 1$)$ in all sampling stations. The highest temperature was recorded $17^{\circ} \mathrm{C}$ at 
station 1 during March and the lowest was recorded $23^{\circ} \mathrm{C}$ at station 9 in April (Table 1).

\section{Salinity}

Mean salinity was recorded $5.07 \pm 0.92 \%$ in all the sampling station. Highest salinity was found $6.7 \%$ at station 2 during March and lowest value 3.9\%o was recorded at station 8, during April 2007 (Table 1). Sediment salinity was inversely correlated with water salinity $(\mathrm{r}=-0.576, \mathrm{P}<0.05, \mathrm{df}=10)$.

\section{Hydrogen ion concentration $(\mathrm{pH})$}

The average $\mathrm{pH}$ of surficial sediment was recorded $6.62 \pm 0.43$ in all sampling stations. $\mathrm{pH}$ was obtained maximum 7.5 at station 9 in April and minimum value was recorded 6.0 at station 4 in March 2007 (Table1). Sediment $\mathrm{pH}$ was positively correlated with water $\mathrm{pH}(\mathrm{r}=$ $0.68, \mathrm{P}<0.05, \mathrm{df}=10)$.

\section{Organic carbon}

The average organic carbon was recorded $1.83 \pm 0.66 \%$ in all sampling stations. The highest organic carbon was recorded 3.63\% at station 9 in April and the lowest was recorded $0.98 \%$ at station 1, during March (Table 1).

\section{Organic matter content}

The mean organic matter was recorded $3.14 \pm 1.13 \%$ in all sampling station. The highest $(6.24 \%)$ organic matter was recorded at station 9 in April and the lowest (1.68\%) organic matter was recorded at station 1, during March (Table 1).

\section{Sediment texture}

The average texture of surficial sediment as sand $87.01 \pm 7.57$, silt $5.23 \pm 1.99$ and clay $8.5 \pm 7.64$ were recorded in the all sampling stations (Table 2). The highest $(94.58 \%$ ) sand was recorded at station 2 in March and the lowest (67.38\%) was recorded at station 9 during April (Table 2). The highest (9.9\%) silt was recorded at station 3 and the lowest (2.49\%) was recorded at station 5 in March (Table 2). The highest $(27.85 \%)$ clay was recorded at station 9 during April and the lowest $(0.57 \%)$ was recorded at station 2 in March (Table 2).

Table 2 Sediment texture in the northern part of Bay of Bengal in Bangladesh coast

\begin{tabular}{lllll}
\hline Period & Station & Sand (\%) & Silt (\%) & Clay (\%) \\
\hline \multirow{4}{*}{ March, 2007 } & 1 & 90.95 & 6.86 & 2.19 \\
& 2 & 94.58 & 4.85 & 0.57 \\
& 3 & 88.55 & 9.9 & 1.55 \\
& 5 & 91.53 & 2.55 & 5.92 \\
& 6 & 82.11 & 2.49 & 15.4 \\
& 7 & 88.32 & 4.21 & 7.47 \\
April, 2007 & 8 & 78.49 & 4.88 & 6.63 \\
& 9 & 67.68 & 5.39 & 14.93 \\
& 10 & 91.88 & 4.77 & 27.85 \\
Mean & 11 & 93.68 & 4.95 & 1.17 \\
\pm SD & - & 87.01 & 5.23 & 1.63 \\
\hline
\end{tabular}

\section{Discussion}

\section{Physico-chemical parameter of subsurface water}

\section{Temperature}

Mahmood et al. ${ }^{16}$ reported the water temperature ranges in between $25.25-27.60^{\circ} \mathrm{C}$ off the coast of Bangladesh in March. Temperature distribution was found relatively uniform in subsurface water. This result is closely agreed with the findings of Kumar et al. ${ }^{17} \mathrm{He}$ stated that the temperature distribution in subsurface water showed thermally homogeneous in the upper $30 \mathrm{~m}$ layer. Sasamal ${ }^{18}$ reported on hydrography of the northern Bay of Bengal, recorded water temperature $>28^{\circ} \mathrm{C}$ in the eastern side and $<26^{\circ} \mathrm{C}$ at about $50 \mathrm{~m}$ depth in a position $19^{\circ} \mathrm{N}$ and $86^{\circ} \mathrm{E}$. He also observed mixed layer depth (MLD) was about $75 \mathrm{~m}$ in the coastal region along $20^{\circ} 30^{\prime} \mathrm{N}$ and $40-50 \mathrm{~m}$ along $19^{\circ} \mathrm{N}$. But still there is scant information about the subsurface water temperature off the Bangladesh coast in the Bay of Bengal.

\section{Salinity}

Mahmood et al. ${ }^{16}$ recorded the water salinity ranges in between $19.68-31.98 \%$ off the coast of Bangladesh during March. Zafar ${ }^{1}$ stated that the average salinity $28.13 \%$ in March and $25.13 \%$ in April in surface water in the northeastern Bay of Bengal. Kumar et al. ${ }^{19}$ found a strong gradient of vertical salinity distribution in the upper $30 \mathrm{~m}, \sim 1.5 \mathrm{psu}$ in the south and $\sim 7 \mathrm{psu}$ in the north of $17^{\circ} \mathrm{N}$, with considerable freshening towards the north between 30 and 100meter the salinity changes with depth were gradual and below 100meter were homogenous. Pati ${ }^{18}$ recorded the maximum salinity from April to June and minimum in October in the Bay of Bengal off the Balashore coast, India. The findings of the present investigation are apparently harmonious with the above-mentioned results.

\section{Hydrogen Ion Concentration (pH)}

Zafar ${ }^{1}$ recorded an average $\mathrm{pH}$ value 8.3 in March and 7.92 in April at surface water of the northeastern part of the Bay of Bengal. Islam, (2001) recorded $\mathrm{pH}$ values 8.2 at $\left(22^{\circ} \mathrm{N}, 91^{\circ} 45^{\prime} \mathrm{E}\right), 8.1$ at $\left(21^{\circ} \mathrm{N}\right.$, $\left.91^{\circ} 15^{\prime} \mathrm{E}\right), 8.3$ at $\left(22^{\circ} \mathrm{N}, 91^{\circ} 45^{\prime} \mathrm{E}\right), 8.1$ at $\left(20^{\circ} \mathrm{N}, 92^{\circ} 15^{\prime} \mathrm{E}\right), 7.1$ at $\left(21^{\circ} \mathrm{N}\right.$, $\left.89^{\circ} 42^{\prime} \mathrm{E}\right), 8.0$ at $\left(21^{\circ} \mathrm{N}, 89^{\circ} 30^{\prime} \mathrm{E}\right)$ respectively in the subsurface water. Generally the alkaline value of $\mathrm{pH}$ in the coastal water of Bangladesh is $6-9 .{ }^{20}$ The outcome of present study shows similar trend of results. There is no available report on subsurface water $\mathrm{pH}$ off the Bangladesh coast in the Bay of Bengal.

\section{Dissolved oxygen (DO)}

The standard DO value of the coastal water of Bangladesh is 6 $\mathrm{ml} / 1 .{ }^{20}$ Mahmood et $a \mathrm{l} .{ }^{16}$ recorded the DO content in water ranges in between 4.20-4.84 ml/1 off the coast of Bangladesh in March. Sasamal $^{18}$ reported that the values of D.O were high at about $50 \mathrm{~m}$ depth in the southern part of central region and low in the western part of the Bay of Bengal along $20^{\circ} 30^{\prime} \mathrm{N}$, oxygen around $0.39 \mathrm{ml} / 1$ was observed in the Swatch of No Ground. The $4 \mathrm{ml} / 1$ contour was located around $30 \mathrm{~m}$ depth in the west and around $75 \mathrm{~m}$ in the east along $19^{\circ} \mathrm{N}$, which extend $50 \mathrm{~m}$ depth along $20^{\circ} 30^{\prime} \mathrm{N}$. The findings of the present study are exclusively agreed with the above mentioned report. In the present study DO in water was found positively correlated with water temperature and negatively with salinity of water. Similar relationship was also found by Satyanarayana et $\mathrm{al}^{21}$ in the fishing ground of Mukka-kaup. Zafarlalso found positive correlation with water temperature and DO in the northeastern part of the Bay of Bengal. 


\section{Surficial sediment parameters}

\section{Sediment salinity}

Hosain ${ }^{6}$ recorded average $2.01 \%$ salinity at selected off shore locations of the St. Martin's Island during pre-monsoon. In the present study sediment salinity showed an inverse relationship with salinity of water $(r=-0.57, \mathrm{P}<0.05)$. Such inverse relationship occurred due to tidal frictional current action in surface water salinity high, but low salinity in sediment comes from rivers, upstream sources where fresh water is existed.

\section{Hydrogen ion concentration $(\mathrm{pH})$}

Grant $^{22}$ recoded the inter-tidal sediment $\mathrm{pH}$ ranged from 7.6 to 8.1 from the inter-tidal sand flat of North Inlet, South Carolina, U.S.A. Islam ${ }^{23}$ recorded $\mathrm{pH}$ values ranged from 6.35 to 6.85 in bottom sediment collected from lower Meghna river estuary during premonsoon. Hosain ${ }^{6}$ found mean $\mathrm{pH}$ value 7.29 at offshore areas of the St. Martin's Island during pre-monsoon. Islam, (2001) recorded $\mathrm{pH}$ values $6.5,6.8,6.8,6.2$ and 7.8 at location $\left(21^{\circ} 85^{\prime} \mathrm{N}, 89^{\circ} 89^{\prime} \mathrm{E}\right)$, $\left(22^{\circ} 10^{\prime} \mathrm{N}, 89^{\circ} 84^{\prime} \mathrm{E}\right),\left(21^{\circ} 89^{\prime} \mathrm{N}, 90^{\circ} 62^{\prime} \mathrm{E}\right),\left(21^{\circ} 52^{\prime} \mathrm{N}, 91^{\circ} 91^{\prime} \mathrm{E}\right)$ and $\left(21^{\circ} 45^{\prime} \mathrm{N}, 92^{\circ} 51^{\prime} \mathrm{E}\right)$ respectively. Chowdhury ${ }^{24}$ recorded soil $\mathrm{pH}$ ranged from 5.2 to 6.5 from sediment sample of Naff river estuary. The findings of present study coincide with the above mentioned results. In the present investigation the surficial sediment $\mathrm{pH}$ showed a positive relation with water $\mathrm{pH}(\mathrm{r}=0.68, \mathrm{P}<0.05)$

\section{Organic carbon}

Islam $^{23}$ reported sediment organic carbon varied from $0.21 \%$ to $0.83 \%$ in a study at the lower Meghna river estuary. High percentage of organic carbon $(0.795 \%$ to $2.379 \%)$ was recorded by Chowdhury (2006) at the Naff river estuary. In the present research work organic carbon content in sediment showed a similar pattern of distribution except a high value $3.63 \%$ at station 9 in the middle fishing ground area $\left(21^{\circ} 02^{\circ} 01^{\prime \prime} \mathrm{N}, 90^{\circ} 34^{\prime} 09^{\prime \prime} \mathrm{E}\right)$. These results are harmonious with findings of present investigation.

\section{Organic matter content}

Kondalarao $^{25}$ reported that organic matter of intertidal zone of the Kinda bay, east coast of India was $0.70 \%$ to $2.17 \%$ which differ with the present observation where organic matter varied from $1.69 \%$ to $6.24 \%$ (Table 1). Alam ${ }^{26}$ reported that $0.952 \%$ to $2.615 \%$ of total organic matter at Halishahar coast. These results showed close agreement with the present findings.

\section{Sediment texture}

Vizakat et al. ${ }^{27}$ expressed that the texture of sediment as silty clay's and silts; silty sand of the subtidal soft sediment of the west coast of India. Alam ${ }^{26}$ recorded the seasonal variation of sediment percentage in the Halishahar coast; Chittagong and he also found maximum sand percentage in monsoon and minimum in winter, which is similar with the present investigation. Hosain ${ }^{6}$ stated the coarser fragments (sandy) were deposited near the shore and the finer particles (clay, silt) at a distance. In the present investigation percentage of clay is higher in the northern part of the Bangladesh coast. Mahadevan et al. ${ }^{28}$ reported highest percentage of sand than silt and clay in the inter-tidal zone in Godavari estuary at maximum sampling stations. Similar findings were also observed in present study.

\section{Conclusion}

Till now there is no available report on physico-chemical parameter of subsurface water and surficial sediment of the Bay of Bengal off the Bangladesh coast. Therefore the present study would be a baseline reference for developing water and sediment quality index of the coastal oceanic zone of the Bangladesh territory.

\section{Acknowledgements}

This research work was a joint venture of the Institute of Marine Sciences and Fisheries and Bangladesh Navy. We sincerely acknowledge both the organizations various help.

\section{Conflict of interest}

The author declares there is no conflict of interest.

\section{References}

1. Zafar M. Study on some Hyrological aspects of the southeastern part of Bangladesh coastal waters in the Bay of Bengal. M Sc thesis. Free University of Brussel. V U B Fundamental and Applied Marine ecology. 1992; 32 p.

2. Islam AKMN. Ecological characteristics of the coastal zone, sunderbans, coastal islands and saline belt. In: Atiq Rahaman, editor. Environmental aspects of surface water system of Bangladesh. 2001; 258 p.

3. Mahmood N, Chowdhury SR, Uddin MM, et al. A review of research works on water quality of the lotic, estuarine and marine environment in Bangladesh. APN- 2001-XX: Bangladesh Chapter. Institute of Marine Sciences and Fisheries, University of Chittagong. Bangladesh. 2002; 24 p.

4. Kabir MJ, Pramanik MAH, Chowdhury MAU. Studies on the coastal accretion and afforestation, for consolidation. Marine Environmental and Rekated ecosystem. Dhaka. Proc Protec. 1979;110-113.

5. Miah MMU. Fertilizer Recommendation Guide. BARC. 2005; 260 p.

6. Hosain MZ. Physico-chemical Parametrers of Sediment in the Intertidal Areas of Saint Martin's Island. M Sc thesis. Institute of Marine Sciences, University of Chittagong, Bangladesh. 2006; 58 p.

7. Zafar M, Hasan CK. Organic carbon in the soils of natural and afforested mangrove of Bangladesh. The J of Noami. 2005;22(2):1-8.

8. Gattuso JP, Frankig M, Wollast R. Carbon and carbonate metabolism in coastal aquatic ecosystem. Annual Review of Ecology and Systematics. 1968;29(1):405-434.

9. Millar CE, Turk LM, Foth HD. Fundamentals of Soil Science. 3rd ed. Soil Science. 1958;86(3):168.

10. www.googleearth.com.

11. Barnes H. Apparatus and methods of oceanography. Part 1, Chemical New York: Interscience Publishers; 1959. 341 p.

12. Petersen L. Analytical Methods Soil, Water, Plant material, Ferilizer SRDI. 2002; $98 \mathrm{p}$.

13. Bouyoucos GJ. Hydrometer method improving for making particle size analysis of soil. Agronomy Journal.1962;54(5):464-465.

14. Jackson ML. Soil chemical analysis. Prentice Hall Pub. Co. Englewood Cliffs, NJ; 1958. $521 \mathrm{p}$.

15. Belaluzzaman MAM. Ecology of the intertidal macro benthic fauna in the Cox's Bazar coastal area, Bangladesh. M. Sc. Thesis, 1995, Institute of Marine Sciences, University of Chittagong. Bangladesh. 1995; 112 p. 
16. Mahmood N, Khan YSA, Ahmed MK. Studies on the hydrology of the Karnafuli Estuary, Bangladesh (Sc). J Asiatic Soc 1976;2(1):88-99.

17. Kumar SP, Muraleedharan Prasad TG, Gauns M, et al. Why is the Bay of Bengal less productive during summr monsoon compared to the Arabian Sea?. Geophysical Research Letters. 2002;29(24):2235.

18. Sasamal SK. Hydrography of the Northern Bay of Bengal during southwest monsoon. DRS. 1989;22(3):105-112.

19. Pati S. Observation on the Hydrography and inshore plankton of the Bay of Bengal off Balashore, India. Hydrobiologia. 1980;70(1-2):123-132.

20. EQS (Environmental Quality standard for Bangladesh) Department of Environment Govt. of the peoples Republic of Bangladesh. 1997.

21. Satyanarayana D, Rao IM, Reddy. Chemical Oceanography of harbour and coastal environment of Visakhapatnam (Bay of Bengal)Part tTrace metals in water and particulare matter. Indian Journal of Marine Sciences.1985;14(3):139-146.

22. Grant J. Factors affecting the occurrence of intertidal amphipods in reducing sediments. J Exp Mar Ecol. 1981;49(2-3);203-216.

23. Islam MI. Study on Bottom Sediment, organic carbon with emphasis on environmental parameters of the lower Meghna estuary, Bangladesh. M. Sc. Thesis. University of Chittagong, Bangladesh. 2004; 97 p.
24. Chowdhury SN. Integrated fisheries management of Naf river estuary for livelihood sustainability of coastal communities. M Sc thesis. Institute of Marine Sciences and Fisheries, University of Chittagong. Bangladesh; 2006. 123 p.

25. Kondalaro B, Murty KV. Ecology of Intertidal Meiofauna of the Kakinda Bay (Gautanu- Godavari Esturine system) East coast of India. J Mar Sc. 1987;17(1):41-47.

26. Alam MM. Study on the heavy metal concentrations in estuarine water and shellfish of the Karnafuli river estuary. Chittagong, M.Sc. Thesis. Institute of Marine Sciences, University of Chittagong, Bangladesh; 1993. $102 \mathrm{p}$.

27. Vizakat L, Harkantra SN, Parulekar AH. Population and community structure of subtidal soft sediment dwelling macro-invertebrates of Konkan, West Coast of India. Ind J of Mar Sc. 1991;20(1):40-42.

28. Mahadevan C, Rao MP. Study on the ocean floor sediments off the east coast of India. Andra Univ Memo Oceanogr. Series No. 49. 1954;1:1-35. 